\title{
TEXT ORGANIZATION OF FORMAL ORAL AND WRITTEN DISCOURSE: AN ANALYSIS BASED ON THE WORK OF BORGES
}

\author{
(A organização textual de discursos formais orais e escritos: \\ uma análise com base na obra de Borges)
}

Ann Montemayor-Borsinger ${ }^{1}$

(Río Negro and Cuyo National Universities, Patagonia-Argentina)

\begin{abstract}
This study examines the text organization of formal oral and written discourse using Systemic Functional Linguistics (SFL), where Theme is considered the point of departure of the message (Halliday 1994, Halliday y Matthiessen 2004). In SFL the succession of Themes as a text unfolds constitutes its 'method of development' (Fries 1983/1995), which is the 'scaffolding' (Stainton 1993) needed for introducing rhematic contributions. Recent work in SFL has suggested that oral English tends towards more 'contentlight' and written English towards more 'contentful' methods of development (Berry forthcoming a \& b). A detailed comparative analysis of the different choices in Theme and grammatical metaphor in thematic position is developed for Spanish, based on conferences by Borges and research articles on his work. Results support the hypothesis that oral discourse, even if it is formal, uses contentlight Themes with interpersonal metaphors whose function is to manifest authorial presence. In contrast written discourse uses contentful Themes with experiential metaphors whose function is to construct highly nominalized methods of development that reduce authorial presence by focusing on abstract entities.
\end{abstract}

1. Ann Montemayor-Borsinger (Lic. Geneva, MEd Bristol, PhD Glasgow) is Professor of Linguistics at Río Negro and Cuyo National Universities, Patagonia, Argentina, and Invited Professor of Discourse Analysis on postgraduate programmes at the University of Buenos Aires. Her research interests focus on functional grammar, discourse analysis, and translation studies. She has published widely, drawing on systemic functional linguistics, to investigate different types of discourse in English, Spanish and French. 
Key words: Systemic Functional Linguistics, textual organization, oral and written discourse.

\section{RESUMO}

Este estudo examina a organização textual de discursos formais, orais e escritos, utilizando a Linguística Sistêmico-Funcional (LSF), proposta teórica em que o Tema é considerado como o ponto de partida da mensagem (Halliday 1994, Halliday y Matthiessen 2004). Desde essa perspectiva, à medida que um texto se expande, a sucessão temática constitui seu 'método de desenvolvimento' (Fries 1983/1995). Trata-se da denominada 'andamiage' necessária para introduzir as contribuições remáticas. Trabalhos recentes em LSF, voltados para o inglês, sugerem que discursos orais tendem a desenvolver estratégias lexicamente mais 'leves' que discursos escritos (Berry, a \&b no prelo). Examina-se tais tendências no espanhol, mediante uma análise comparativa baseada em conferências orais de Borges e artigos escritos produzidos sobre seus trabalhos. Para tanto, realiza-se um estudo detalhado das diferentes opções no uso de Tema $e$ de metáfora gramatical em posição temática. Os primeiros resultados do estudo apóiam a hipótese de que o discurso oral, mesmo que formal, utiliza Temas lexicamente leves, com metáforas interpessoais, cuja função é manifestar a presença do autor. $O$ discurso escrito, a contrário, exibe Temas lexicamente densos, com metáforas experienciais, cuja função é reduzir a presença do autor, mediante a focalização centrada em entidades abstratas, altamente nominalizadas.

Palabras-chave: Linguística Sistémico Funcional, organização textual, discursos orais e escritos.

\section{Introduction}

This study examines text organization of formal oral and written discourse in or inspired by the work of the famous Argentine writer, Jorge Luis Borges. The consideration in Systemic Functional Linguistics of Theme as the starting point of the message rather than as given information (Halliday 1994 vs Firbas 1992) provides pedagogically relevant perspectives for the study of discourse organization (Eggins 2004, Halliday and Matthiessen 2004, Martin and Rose 2008). The 
analysis is based on Theme choice because Theme "has to do with the particular angle one takes on the content of a text in its development" (Martin 1985: 27) and represents what is selected to "organize and carry forward the discourse" (Halliday and Matthiessen 2004: 65).

One important challenge is how to move from the theoretical concept of Theme as point of departure to its instantiation in text, to gain a better understanding of the variations that affect textual organization in different registers. Pioneering register-based studies such as those of Berry (1989), Martin (1985) and Davies (1988) have been highly relevant for English. Recently Berry (forthcoming a \& b) has revisited the 'method of development' (Fries 1983, 1995) of the text as it unfolds, and analyses which thematic choices are most relevant to distinguish successful spoken from successful written English. This dynamic structuring of textual meanings can also be seen as the 'scaffolding' (Stainton 1993) which prepares the hearer for the contribution, for what is the very purpose of the discourse, for the Rheme.

The present work develops these ideas on the basis of a comparative analysis of excerpts taken from a corpus of socially valued texts in Spanish, on the one hand conferences Borges gave at university, and on the other research articles on his work. We herein analyze the structuring functions of the different types of Theme choice for oral versus written registers, based upon the concepts of marked, unmarked and multiple Theme proposed by Systemic Functional Linguistics (SFL), with a special consideration of experiential and interpersonal grammatical metaphors in thematic position.

The paper is organized as follows. Sections 2 and 3 develop theoretical considerations on Theme and grammatical metaphor respectively, while Section 4 develops methodological considerations on the types of clause considered for the analysis. Section 5 discusses the results of a detailed comparative analysis of excerpts from a conference, on the one hand, and from a research article on the other. The last section reflects on the importance of a dynamic and discourse based view of the succession of Themes in text, and on the similarities found in systemic functional research in Theme choices in English and in Spanish 


\section{The notions of marked, unmarked and multiple Theme}

According to Systemic Functional Linguistics (SFL), upon emitting a message, we must decide how it will begin. The part that comes first, the Theme, expresses important types of meanings because its initial position is usually used to signal how we have chosen to develop a text and orient the reader or listener. At the level of discourse, the succession of Themes represents the method of development chosen for a given text. As a rule of thumb, the first element or group of elements having a function in the 'experiential' structure of the clause is considered to be the Theme (Halliday 1994:38). Note that according to SFL, all texts are composed of three types of meanings which function simultaneously to construct a model of experience (the 'experiential' metafunction), represent social interactions (the 'interpersonal' metafunction) and organize experiential and interpersonal meanings to create relevant texts (the 'textual' metafunction). Each of these three metafunctions has a preferred type of lexico-grammatical structure. The structure related to the experiential metafunction is segmented in a process (or verb, in terms of traditional grammar) with its associated participants and circumstances; the structure related to the interpersonal metafunction centers on the grammatical subject and finite part of the verb, while the structure related to the textual metafunction organizes the message in Theme, the starting point of the message, and Rheme, the development of the message. Consider the first sentence in Emma Zunz by Borges (Theme in bold print):

(1) El catorce de enero de 1922, Emma Zunz, al volver de la fábrica de tejidos Tarbuch y Loewenthal, halló en el fondo del zaguán una carta, fechada en el Brasil, por la que supo que su padre había muerto...

(2) On January fourteenth, 1922, Emma Zunz, upon returning from the Tarbuch and Loewenthal textile mill, found a letter at the back of the entrance hall, postmarked in Brazil, from which she learned that her father had died... 
Here, from the standpoint of the experiential metafunction, the process found has two participants, Emma Zunz and a letter, and several circumstances. If a circumstance is in the first position, as in On January fourteenth, 1922, from the perspective of the textual metafunction it is the starting point of the message, the Theme, and the rest of the sentence is the Rheme. It is also a 'marked' Theme, because it could be absent or located in a different position, but this starting point was chosen for a reason that is functional to the text as a whole. The word order might also have been (Theme in bold print):

(3) Emma Zunz, al volver de la fábrica de tejidos Tarbuch y Loewenthal, halló el catorce de enero de 1922 una carta, fechada en el Brasil ...

(4) Emma Zunz, upon returning from the Tarbuch and Loewenthal textile mill, found, on January fourteenth, 1922 a letter, postmarked in Brazil ...

If this had been Borges' choice (which it is not) the Theme would have been Emma Zunz, and it would be considered in SFL theory as 'unmarked' because it is both the starting point of the message and its grammatical subject. Why 'unmarked'? Because looking back at traditional western grammars, (e.g. Weil 1844), we find that they distinguish an order of words in harmony with a kind of 'ordo naturalis' of the Subject-Verb-Object kind. It is argued that if there is no particular reason to break with this order, the starting point of the message will be the Subject and will thus be an unmarked Theme.

Hence, Theme ends with the first participant, process or circumstance in the sentence, i.e. it finishes when it reaches this initial element which also has an experiential function, and which Halliday calls 'topical Theme' (Halliday and Matthiessen 2004:79). There may also be what SFL calls 'multiple' Themes when elements of textual or interpersonal origin precede the experiential 'topical Theme'. If the function of such elements is to connect parts of the discourse, e.g. as in the case of conjunctions such as nevertheless, but, moreover, etc., they 
are textual Themes. If the function is to express attitudes or opinions, the Themes will be interpersonal, as in the case of adverbs such as probably, or elements that project the opinion of the speaker by means of a projecting clause of the type I think as in I think Montaigne (is right), because Halliday sees it as an interpersonal metaphor (Halliday and Matthiessen 2004: 613). If either of these types of textual and interpersonal elements precedes the Theme of experiential origin, they are also part of the Theme, though they are not sufficient to actually fully constitute the starting point of the message. To do so, the sentence must be analysed from left to right, because the criterion is initial position, until the first truly experiential element is found.

The Appendix includes the analysis of excerpts from the Borges texts in Spanish using the concepts we have just examined. Tables 1 and 2 in Section 5 below show the Themes translated to English with examples of marked, unmarked and multiple Themes (i.e. Themes preceded by textual or interpersonal elements) in each table.

\section{The notion of grammatical metaphor}

SFL distinguishes between 'lexical' metaphor and 'grammatical' metaphor. In grammatical metaphor, which is of special interest to SFL, the shift is not from one lexical element to another, but from one grammatical category to another. Halliday thus considers lexical metaphor as a change in the meaning of an expression, and grammatical metaphor as a change in the way in which a meaning is expressed (e.g. Halliday and Matthiessen 2004: 626). There are two main types of grammatical metaphors, experiential and interpersonal ones.

3.1 Experiential grammatical metaphors: different representations of content

An important function of experiential grammatical metaphors is to transform what was originally a clause with an agent, to an agentless 
nominal group. One example of such a shift is to change from the clause category Librarians destroy books to the agentless nominal group category The destruction of books found in a scholarly article on the work of Borges. Both expressions construct a similar type of event, but with a shift in the way they are expressed. The purpose of the shift to the second expression is to allow the construction of chains of argument typical of formal written registers of the type: The destruction of books causes horror. This type of sequence - i.e. "x" causes "y" - enables analytical developments that are essential for exchanging and creating knowledge in academic discourse. Moreover, thanks to this type of 'Instantial' expression, abstract entities such as theories, hypotheses, models and categories can be presented to the reader as facts that are supposedly external to the writer. We shall see further on that this is exactly what the Borges scholar repeatedly does in his article.

\subsection{Interpersonal grammatical metaphors: different represen- tations of authorial presence}

Here again, SFL regards metaphor not as a change in the meaning of an expression, but as a change in the way in which a meaning is expressed. One example of such a shift is to move from the agentless adverb category probably to the projecting clause category with explicit agent I would say that. They both project a similar type of opinion, but are expressed differently. Take, for example, a statement from the conference by Borges, I would say that literature is also a form of happiness. In fact, the expression I would say that works metaphorically as a modal adjunct that softens the statement is a form of happiness.

It would have been possible to say something like literature is also probably a form of happiness, or literature might also be a form of happiness, but here the speaker Borges wishes to attribute the responsibility of saying that literature is a form of happiness explicitly to himself rather than implicitly by means of probably or might. In order to do so, throughout his conference he makes use of interpersonal metaphors by including projecting clauses in multiple Themes. 


\section{Type of clauses considered for studying Theme}

We now need to define the limits of the clauses considered for the analysis of Theme in our comparative study. We shall consider only paratactic clauses, similar to work done for example by Martin (1985, 1992), where each clause is a component with equal status within a sentence and each could function independently. In other words, the Themes of subordinate or hypotactic clauses are not analyzed separately within a sentence.

Moreover, the choice of punctuation in written text, particularly the full stop or period, is deliberate and serves to define a dominant thematic pattern. This justifies omitting the analysis of subordinate clauses and focusing on paratactic clauses, in order to provide a clearer picture of thematic patterns in text without the interference of secondary organization. Similarly, punctuation in the highly formal conferences Borges gave at university also serves to define a dominant thematic pattern.

\section{Themes in oral and written discourse}

As an example of the heuristics of Theme in accounting for different organizational patterns in formal oral and written discourse in Spanish, we shall analyze excerpts from two texts in detail. In order to facilitate the comparison, we selected excerpts of the same length (about 650 words) from texts with similar topics related to books. The first is taken from a conference by Borges on the book and the second from an article that analyses his Library of Babel by a Borges scholar, Rivas Casasayas. This article was originally published in 1999 in a Spanish Journal, and then published again the following year by another journal from the Springer Verlag group in the Netherlands. The relevant tables of analysis of the original texts in Spanish are included in the Appendix. In the following, Themes have been translated to English. Partly due to the formal nature of these texts, the thematic analysis for Spanish and English is the same for the written register. It only differs somewhat in the conference because of obligatory Subject in English. 


\subsection{Method of development in oral discourse}

The text from the conference by Borges has 23 Themes, with 3 marked Themes, two circumstances of place (About the book, In this essay), and one circumstance of time (many years ago) at the beginning of the excerpt, whose function is to situate the audience in the here and now of the conference:

Unmarked Themes have to do with human participants: Borges expresses himself directly as $I$, involves his sister, blends his own voice with that of his literary predecessors (in the excerpt, the voices of Joyce and Montaigne) and directly involves the audience with If we (read). Human participants are present in nearly all the Themes except for two marked Themes (About the book and In this essay) and two unmarked Themes (A book and happiness).

Table 1: Themes showing the Method of Development of the conference

\begin{tabular}{|l|l|l|}
\hline \multicolumn{3}{|c|}{ Theme } \\
\hline Textual/Interper. & Marked & Unmarked \\
\hline & About the book & \\
\hline First & & I \\
\hline & & I \\
\hline & In this essay & \\
\hline & & Montaigne \\
\hline Because & & He \\
\hline I remember & & He \\
\hline & many years ago & \\
\hline And & & They \\
\hline I would say that & & She \\
\hline & & literature \\
\hline So I think & & If we \\
\hline & & a writer like Joyce \\
\hline & & A book \\
\hline I think & & happiness \\
\hline
\end{tabular}




\begin{tabular}{|l|l|l|}
\hline Then & & he \\
\hline & & He \\
\hline & & he \\
\hline & & I \\
\hline But & & this \\
\hline & & Montaigne \\
\hline But &, & he \\
\hline
\end{tabular}

There are several multiple Themes, most of which include elements realized by interpersonal grammatical metaphors which explicitly express the author's opinion. The excerpt illustrates these explicit opinions in thematic position in I remember(many years ago), I would say that (literature), So I think (a writer like Joyce) and I think (Montaigne). There are no instances of nominalizations that make use of experiential grammatical metaphor. This strong presence of $I-$ alone or blended with other voices - both in unmarked Themes and in interpersonal metaphors characteristic of the multiple Themes in this text, make authorial presence explicit throughout the method of development of the conference.

\subsection{Method of development in written discourse}

Although the excerpt from the article about the work of Borges is the same length, it has only 14 Themes compared to the 23 Themes in the conference, showing longer sentences. Marked Themes are not concerned anymore with time and place but with more complex meanings as in According to this norm and From the narrative logic of the story:

\section{Table 2: Themes showing the Method of Development of the research article}

\begin{tabular}{|l|l|l|}
\hline \multicolumn{3}{|c|}{ Theme } \\
\hline Text/Inter & Marked & Unmarked \\
\hline & & $\begin{array}{l}\text { Another contradiction, more in } \\
\text { keeping with this logic of the whole } \\
\text { present in the narrative, }\end{array}$ \\
\hline
\end{tabular}




\begin{tabular}{|l|l|l|}
\hline & & The library \\
\hline $\begin{array}{l}\text { but it so happens } \\
\text { that }\end{array}$ & some librarians \\
\hline & for the librarian & The destruction of books \\
\hline But & $\begin{array}{l}\text { the destruction of books (if of one } \\
\text { only) }\end{array}$ \\
\hline $\begin{array}{l}\text { But the fact remains } \\
\text { that }\end{array}$ & $\begin{array}{l}\text { the library in its entirety according to } \\
\text { the combinations of signs }\end{array}$ \\
\hline And not only & $\begin{array}{l}\text { Any alteration of the library in its } \\
\text { entirety }\end{array}$ \\
\hline On the other hand & the addition of books \\
\hline It jeans & $\begin{array}{l}\text { an addition, the repetition of something } \\
\text { that already exists, }\end{array}$ \\
\hline & Any written communicative act \\
\hline & $\begin{array}{l}\text { According to } \\
\text { this norm }\end{array}$ & $\begin{array}{l}\text { From } \\
\text { narrative logic } \\
\text { of the story }\end{array}$ \\
\hline But & the & \\
\hline
\end{tabular}

The unmarked Themes are also highly nominalized, and lack explicit authorial presence. They focus on abstract entities such as the narrative, the library in its entirety, and agentless beliefs and actions expressed by compound nouns that make use of experiential grammatical metaphor. Some examples from the excerpt are: Another contradiction, more in keeping with this logic of the whole present in the narrative, The destruction of books, Any alteration of the library in its entirety, the addition of books, and Any written communicative act.

There are fewer multiple Themes, most of which contain elements of textual origin (But, And, On the other hand) Those containing interpersonal elements do not express the author's opinion explicitly, but implicitly by means of impersonal constructions such as it so happens that, and the fact remains that. 


\section{Final remarks}

This analysis shows that text organization in oral and written discourse differs clearly, even in formal oral registers such as the conference. This is in keeping with extensive Systemic Functional research for English, with classics such as Halliday's Spoken and Written Language published in 1989, early studies taking into account English and Spanish such as in Taboada (1995), and recent qualitative studies for English such as in Berry (forthcoming a \& b.).

The succession of Themes at the level of discourse, i.e. the method of development specific to the text, shows that in the conference most Themes have to do with the speaker, who appears explicitly as "I-Borges", or together with fellow writers. In more general terms, the method of development is constructed around two lexical chains: "I-Borges" + "other authors". It is a contentlight method of development that uses personal pronouns and simple nouns, with no experiential but plenty of interpersonal grammatical metaphor. Texts that are spoken tend to use this type of metaphor as points of departure to form sequences with strong authorial presence in contexts of situation where speaker and audience are in contact, implying a more interactive and dynamic staging of discourse with attitudinal lexis.

In contrast, in the research paper, the method of development is constructed around the entities "texts by Borges" + "the library" + "librarians' beliefs" + "librarians' actions". It is a contentful method of development made up of complex nouns that make use of experiential metaphor. By eliding authorial presence, what are in fact hypotheses and theories appear to be more objective in contexts of situation that ask for textual organizations with apparently neutral lexis.

The study of the options made in Theme, and the presence or absence of experiential and interpersonal metaphor, allows for a finer analysis of the discursive modalities of argumentation in formal oral and written discourse in Spanish. Other studies have focused on the changes that occur when moving from formal written to more informal oral discourse. We have already mentioned one of the more recent and 
relevant studies in this respect made by Berry (forthcoming a \& b). Interestingly, even in the highly formal Spanish texts discussed here the findings are similar, with formal oral registers tending towards lighter methods of development than written registers. With pedagogical applications in mind, this analysis illustrates possible thematic options for increasing the effectiveness of communication in a variety of formal contexts.

Recebido em: julho de 2013 Aprovado em: setembro de 2013 aborsinger@gmail.com

\section{References}

BERRY M. Thematic options and success in writing in C.S. Butler, R.A. Cardwell and J. Channel (eds) Language \& Literature - Theory \& Practice: A Tribute to Walter Grauberg. Nottingham: University of Nottingham Press, 1989, p. 62-80.

BERRY, M. Towards a study of the differences between formal written English and informal spoken English. In Lise Fontaine, Thomas Bartlett and Gerard O'Grady (eds.) Systemic Functional Linguistics: Exploring Choice. Cambridge: Cambridge University Press, forthcoming.

BERRY, M. Contentful and contentlight Subject Themes in informal spoken English and formal written English. In Gerard O'Grady, Lise Fontaine and Thomas Bartlett (eds.) Choice in Language. London: Equinox, forthcoming.

DAVIES, F. Reading between the lines: Thematic choice as a device for presenting written viewpoint in academic discourse. ESPecialist, Vol. 9, Nos 1/2. 173-200, 1988.

EGGINS, S. An Introduction to Systemic Functional Linguistics. London: Pinter Publishers, 2004.

FIRBAS, J. Functional sentence perspective in written and spoken communication Cambridge: Cambridge University Press, 1992.

FRIES, P. On the Status of Theme in English: Arguments for Discourse. In 
Pertofi J.S. and Sozer E. Micro and Macro Connexity of Texts: Papers in Text Linguistics. Hamburg: Helmut Burk, 1983.

FRIES, P. Themes, Methods of Development, and Texts. In Hasan R. and Fries P. (eds.) On Subject and Theme: A Discourse Functional Perspective. Amsterdam: John Benjamins, 1995.

HALLIDAY, M.A.K. Spoken and Written Language. Oxford: Oxford University Press, 1989.

HALLIDAY, M.A.K. An Introduction to Functional Grammar. London: Edward Arnold, 1994.

HALLIDAY, M.A.K. and MATTHIESSEN, C.M.I.M. An Introduction to Functional Grammar. London: Edward Arnold, 2004.

MARTIN, J.R. Factual writing: exploring and challenging social reality. Oxford: Oxford University Press, 1985.

MARTIN, J.R. English Text: System and Structure. Amsterdam: John Benjamins, 1992.

MARTIN, J.R. and ROSE D. Genre Relations. Mapping Culture. London: Equinox, 2008.

TABOADA, M.T. Building Coherence and Cohesion: Task-oriented dialogue in English and Spanish Amsterdam: John Benjamins, 1995.

STAINTON, C. Metadiscourse and the Analytical Text: a Genre-based Approach to Children's Written Discourse. Unpublished $\mathrm{PhD}$ Thesis. Manchester : University of Manchester, 1993.

WEIL, H. De l'ordre des mots dans les langues anciennes comparées aux langues modernes Paris: Librairie A. Franck, 1844.

\section{Corpus}

BORGES, J.L. Borges Oral. In Obras Completas, Tomo IV. Buenos Aires: Emecé Editores, 1979, p. 163-179.

RIVAS CASASAYAS, A. Signos Mágicos y de lo Absoluto: Aproximación a Términos y Conceptos de Filosofía del Lenguaje en Tres Cuentos de Jorge Luis Borges. Neophilologus, Vol 84, No 4: 555-575, 2000. Originally published in Signa 8, 1999. 


\section{Appendix}

For reasons of space only excerpts of the complete analysis of the original text in Spanish are shown.

\section{Example of analysis of Borges Oral: El libro}

\begin{tabular}{|c|c|c|c|c|}
\hline \multicolumn{4}{|c|}{ Theme } & \multirow[t]{2}{*}{ Rheme } \\
\hline textual & interpersonal & $\begin{array}{l}\text { experiential } \\
\text { (Topical Theme) } \\
\text { marked }\end{array}$ & $\begin{array}{l}\text { experiential } \\
\text { (Topical } \\
\text { Theme) } \\
\text { unmarked }\end{array}$ & \\
\hline & & Sobre el libro & & $\begin{array}{l}\text { han escrito de un modo } \\
\text { tan brillante tantos } \\
\text { escritores. }\end{array}$ \\
\hline & & & Yo & $\begin{array}{l}\text { quiero referirme a unos } \\
\text { pocos. }\end{array}$ \\
\hline \multirow[t]{4}{*}{ Primero } & & & me & $\begin{array}{l}\text { referiré a Montaigne, que } \\
\text { dedica uno de sus ensayos } \\
\text { al libro. }\end{array}$ \\
\hline & & En ese ensayo & & $\begin{array}{l}\text { hay una frase memorable: } \\
\text { "No hago nada sin } \\
\text { alegría". }\end{array}$ \\
\hline & & & Montaigne & $\begin{array}{l}\text { apunta a que el concepto } \\
\text { de lectura obligatoria es } \\
\text { un concepto falso. }\end{array}$ \\
\hline & & & Dice & $\begin{array}{l}\text { que si él encuentra un } \\
\text { pasaje difícil en un libro,lo } \\
\text { deja; }\end{array}$ \\
\hline \multirow[t]{3}{*}{ porque } & & & ve & $\begin{array}{l}\text { en la lectura una forma de } \\
\text { felicidad. }\end{array}$ \\
\hline & Recuerdo que & $\begin{array}{l}\text { hace muchos } \\
\text { años }\end{array}$ & & $\begin{array}{l}\text { se realizó una encuesta } \\
\text { sobre qué es la pintura. }\end{array}$ \\
\hline & & & $\mathrm{Le}$ & $\begin{array}{l}\text { preguntaron a mi } \\
\text { hermana Norah }\end{array}$ \\
\hline $\mathrm{y}$ & & & contestó & $\begin{array}{l}\text { que la pintura es el arte de } \\
\text { dar alegría con formas y } \\
\text { colores. }\end{array}$ \\
\hline
\end{tabular}




\begin{tabular}{|c|c|c|c|c|}
\hline & Yo diría que & & la literatura & $\begin{array}{l}\text { es también una forma de } \\
\text { la alegría. }\end{array}$ \\
\hline & & & Si leemos & $\begin{array}{l}\text { algo con dificultad, el } \\
\text { autor ha fracasado. }\end{array}$ \\
\hline \multirow[t]{4}{*}{ Por eso } & considero que & & $\begin{array}{l}\text { un escritor } \\
\text { como Joyce }\end{array}$ & $\begin{array}{l}\text { ha fracasado } \\
\text { esencialmente, porque su } \\
\text { obra requiere un esfuerzo. }\end{array}$ \\
\hline & & & Un libro & $\begin{array}{l}\text { no debe requerir un } \\
\text { esfuerzo, }\end{array}$ \\
\hline & & & la felicidad & $\begin{array}{l}\text { no debe requerir un } \\
\text { esfuerzo. }\end{array}$ \\
\hline & Pienso que & & Montaigne & tiene razón. \\
\hline \multirow[t]{4}{*}{ Luego } & & & enumera & los autores que le gustan. \\
\hline & & & Cita & a Virgilio, \\
\hline & & & dice & $\begin{array}{l}\text { preferir las Geórgicas a la } \\
\text { Eneida; }\end{array}$ \\
\hline & & & yo & prefiero la Eneida, \\
\hline \multirow[t]{2}{*}{ pero } & & & eso & no tiene nada que ver. \\
\hline & & & Montaigne & $\begin{array}{l}\text { habla de los libros con } \\
\text { pasión, }\end{array}$ \\
\hline pero & & , & dice & $\begin{array}{l}\text { que aunque los libros } \\
\text { son una felicidad son, } \\
\text { sin embargo, un placer } \\
\text { lánguido. }\end{array}$ \\
\hline
\end{tabular}

